\title{
PENGELOLAAN BUKU ADMINISTRASI DESA DI DESA SUNGAI SIPAI KECAMATAN MARTAPURA KABUPATEN BANJAR
}

\author{
Jumarianta \\ FIA, Universitas Achmad Yani Banjarmasin \\ Email: masjumwae@yahoo.co.id
}

\begin{abstract}
The aim of this research is to find out how the Management of Village Administration Books in the Sipai River Pambakal Office Sungai Sipai Village, Martapura District, Banjar Regency.This study uses a qualitative descriptive method, the data digger is in the form of interviews for primary data, and observation and documentation for secondary data. Based on the results of the analysis and discussion, the researchers concluded that the Village Government consisted of Village heads and other Village Tools, namely Secretary, Treasurer, Head of Government Affairs, Head of Development Affairs, Head of General Affairs, and Head of RT, according to local village conditions. In the management of village administration there are several models of village administration books, namely, general administration books, population administration books, financial administration books, development administration books, administration books for village consultative bodies, and other administrative books. The books are already filled in completely, but some are not complete. To further optimize the technical and performance of the Village Administration Book Management, it is recommended to further improve the capacity of the village apparatus and the technical management of the administration book through training and workshops so that the management of the village administration book is getting better.
\end{abstract}

Keywords: management, administration, village

\section{PENDAHULUAN}

Semenjak bergulirnya era reformasi yang berdampak pada terjadinya pergeseran paradigma sistem pemerintahan yang bercorak sentralistik menjadi sistem pemerintahan yang desentralistik. Otonomi daerah yang memberikan keleluasaan kepada daerah untuk mengatur dan mengurus kepentingan masyarakat setempat berdasarkan prinsip-prinsip demokrasi dan peran serta masyarakat sendiri atas pemerataan dan keadilan sesuai dengan kondisi, potensi dan keragaman daerah otonomi masingmasing.

Perubahan sistem pemerintahan tersebut juga berdampak pada tataran pemerintahan kecamatan dan desa, yaitu kecamatan tidak lagi menjalankan urusan-urusan dekosentrasi yang merupakan urusan pemerintah pusat yang ada di daerah. Urusan-urusan tersebut sudah menjadi wewenang bagi pemerintah desa dalam melaksanakan, mengkoordinasikan pembangunan dan membina kehidupan masyarakat di berbagai bidang, dengan begitu pemerintahan desa menjadi kunci dalam pelaksanaan otonomi daerah.

Sejak kebijakan otonomi daerah diberlakukan telah banyak membawa dampak yang sangat luas bagi penyelenggaraan pemerintahan, perencanaan pembangunan, pengelolaan keuangan dan sistem penganggaran dalam menunjang penyelenggaraan pemerintahan di daerah khususnya pada tingkat pemerintahan desa. Kebijakan otonomi daerah tersebut bertanggung jawab dalam penyelenggaraan pemerintahan di Indonesia. Reformasi dan otonomi daerah sebenarnya adalah harapan baru bagi pemerintah dan masyarakat desa untuk membangun desanya sesuai kebutuhan dan aspirasi masyarakat. Bagi 
sebagian besar aparat pemerintah desa, otonomi adalah suatu peluang baru yang dapat membuka ruang kreativitas bagi aparatur desa dalam mengelola desa.

Administrasi pemerintah memegang peranan yang penting karena keterlibatan pemerintah yang besar pada proses pembangunan dalam sistem administrasi. Untuk itu agar tujuan pembangunan benar-benar dapat tercapai seperti yang diharapkan, maka yang harus diperhatikan adalah adanya aparat pemerintah yang memiliki kualitas yang memadai. Kualitas tersebut selain dilandasi kemampuan dan keterampilan yang memadai juga harus disertai disiplin yang tinggi, sehingga dalam merealisasikan tujuan-tujuan nasional sesuai dengan kebijaksanaan pembangunan yang ditetapkan pemerintah, dengan titik berat pembangunan perlu diarahkan pada masyarakat pedesaan karena sebagian besar penduduk Indonesia bertempat tinggal di pedesaan.

Hakekat pembangunan desa bertujuan untuk memperbaiki kondisi dan taraf hidup masyarakat. Di samping itu pemerintah desa merupakan strategi pembangunan yang memungkinkan pemerataan pembangunan, pertumbuhan ekonomi yang cukup tinggi serta tercapainya stabilitas keamanan wilayah yang sehat dan dinamis serta hasil-hasilnya dinikmati oleh rakyatnya. Pemerintah desa sebagai alat untuk mencapai tujuan administrasi negara, berfungsi sebagai penyelenggaraan urusan pemerintah dalam rangka pembangunan nasional demi tercapainya kesejahteraan rakyat yang merata diseluruh tanah air.

Pengaturan tentang administrasi desa bertujuan untuk menjadikan desa lebih mandiri, tanpa harus selalu bergantung pada pemerintahan diatasnya. Selain itu tujuan dari administrasi desa ialah untuk menjadi landasan dasar dalam setiap pengambilan keputusan oleh pemerintah terkait pembangunan nasional. Berbagai kendala dialami oleh desa dalam melakukan administrasi desa, antara lain keterbatasan kapasitas aparatur desa. Desa masih sangat tergantung dari bantuan pemerintah pusat dan daerah dalam mengurusi segala permasalahan yang ada di wilayahnya. Oleh karena itu, diperlukan aparatur pelaksana yang mampu memahami, mengkaji dan menelaah serta menyelesaikan permasalahan yang timbul, sebagai konsekuensi logis dari pada usaha penyempurnaan aparatur pemerintahan maka akan dapat menambah kemampuan aparatur pemerintah dalam melakukan fungsi perencanaan, pelaksanaan, dan pengawasan. Tingkat kemampuan dan keterampilan aparat desa belum memenuhi keinginan yang diharapkan sesuai dengan tingkat perkembangan, pengaturan dan penyelenggaraan pemerintahan desa.

Untuk menyelenggarakan administrasi desa yang efektif diperlukan pembinaan dan pengawasan yang dilakukan oleh pemerintah kecamatan terhadap aparatur pemerintah desa dalam bidang pemerintahan, sehingga perangkat desa dapat melakukan tugas dan kewajibannya dengan baik dalam melayani masyarakat. Pembina administrasi desa yang dijalankan adalah untuk mengembangkan sistem administrasi pemerintahan desa yang berfungsi sebagai sumber data dan informasi bagi seluruh aktifitas pemerintahan dalam pembangunan secara nasional. Untuk meningkatkan manajemen pemerintahan desa perlu dilakukan penataan administrasi agar lebih efektif dan efisien, penataan administrasi merupakan pencatatan dan informasi dalam mendukung penyelenggaraan pemerintahan desa maka dilakukan penyempurnaan terhadap pelaksanaan administrasi.

Pemerintah kecamatan sangat dituntut untuk turut berperan aktif dalam usaha pembinaan dan pengawasan administrasi yang dilakukan untuk aparatur pemerintah desa, sehingga akan terwujud pelaksanaan administrasi yang tertib dan mendorong pelaksanaan pemerintahan di wilayah pedesaan.

Agar desa mampu menggerakkan, mengatur, mengendalikan dan mendorong masyarakat untuk memajukan desa dengan pembangunannya dibutuhkan seorang kepala desa dan perangkat desa yang berhasil guna dan berdaya guna serta profesional. Selain itu perangkat desa juga harus bersih, produktif, berwibawa, transparan, inovatif, peka, antisipasif dan proaktif, serta juga mempunyai visi (Siagian, 2008).

Selain melaksanakan tugas-tugas umum pemerintahan camat juga melaksanakan 
kewenangan pemerintahan yang dilimpahkan oleh pemerintahan diatasnya untuk menangani sebagian urusan otonomi daerah, yang meliputi aspek perizinan, rekomendasi, koordinasi, pembinaan, pengawasan, fasilitasi, penetapan, penyelenggaraan, kewenangan lain yang dilimpahkan. Pelimpahan sebagian wewenang ini dilakukan berdasarkan kriteria eksternalitas dan efisiensi. Eksternalitas yang dimaksud adalah kriteria pelimpahan urusan pemerintahan dengan memperhatikan dampak yang timbul sebagai akibat dari penyeleggaraan suatu urusan pemerintahan. Apabila dampak yang ditimbulkan bersifat internal Kecamatan, maka urusan pemerintahan tersebut menjadi kewenangan camat. Sedangkan yang dimaksud dengan efisiensi adalah kriteria pelimpahan urusan pemerintahan dengan memperhatikan daya guna tertinggi yang dapat diperoleh dari penyelenggaraan suatu urusan pemerintahan dilingkup Kecamatan, maka urusan tersebut menjadi kewenangan Camat.

Sukses tidaknya pemerintahan desa sangat tergantung dengan administrasi desa. Administrasi dapat berjalan dengan baik apabila kualitas manusia sebagai sumber daya insani dapat melaksanakan dengan sebaik mungkin artinya administrasi desa sangat menentukan kedudukan pemerintahan desa. Administrasi desa merupakan tolak ukur keberhasilan pemerintahan desa karena merupakan fondasi dalam memperkuat dan mengembangkan pemerintahan desa. Jadi administrasi desa merupakan prioritas utama yang harus mendapat perhatian serius oleh pemerintah khususnya Pemerintah Kecamatan.

Sebagaimana kita ketahui bahwa desa adalah suatu wilayah yang ditempati oleh sejumlah penduduk sebagai kesatuan masyarakat termasuk didalamnya kesatuan hukum yang mempunyai organisasi pemerintahan terendah di bawah Camat dan berhak menyelenggarakan rumah tangganya sendiri dalam ikatan Negara Kesatuan Republik Indonesia.

Berbicara tentang administrasi desa maka yang dimaksud dengan administrasi desa adalah rangkaian kegiatan yang dilakukan oleh penyelenggaraan pemerintah desa untuk mencapai tujuan yaitu pemerintah desa yang mampu menggerakkan masyarakat dengan kemampuan partisipasinya dalam pembangunan guna peningkatan taraf hidup masyarakatnya.

Dalam pengertian sempit administrasi desa adalah segenap proses penyelenggaran kegiatan tulis-menulis, surat-menyurat beserta penyimpanan, pengurusan naskah-naskah dan segala pencatatan-pencatatan yang dilaksanakan oleh aparat atau perangkat desa dalam rangka mencapai tujuan.

Pemerintah desa merupakan bagian integral dari pemerintah pusat maka tujuan pemerintahnya sama dengan tujuan pemerintah nasional dalam pembukaan Undang-Undang dasar 1945 alinea ke empat, yakni melindungi segenap tumpah darah Indonesia, memajukan kesejahteraan umum, mencerdaskan kehidupan bangsa, dan ikut melaksanakan ketertiban dunia.

Mengelola administrasi desa pada saat ini sangatlah penting, hal ini akan mengakibatkan tertibnya administrasi di desa-desa. Pemerintah sudah memberikan pedoman untuk administrasi desa yang telah di Undang-Undangkan dan mungkin setiap desa sudah memilikinya melalui sosialisasi.

Berbagai model buku administrasi desa harus dimiliki agar desa menjadi tertib administrasi, walaupun kenyataannya mungkin dianggap sulit, tetapi hal ini menjadi tantangan bagi aparatur desa untuk bisa menertibkan administrasinya. Namun, beberapa model buku administrasi desa yang terdapat di Kantor Pambakal Sungai Sipai Desa Sungai Sipai Kecamatan Martapura Kabupaten Banjar masih kurang lengkap dan pengelolaannya masih kurang maksimal serta minimnya ketersediaan lahan dan bangunan yang dimiliki membuat administrasi desa menjadi terhambat dalam pelayanan kepada masyarakat setempat sehingga perlu untuk diteliti.

Guna mengetahui bagaimana pengelolaan administrasi desa di Kantor Pambakal Sungai Sipai Desa Sungai Sipai Kecamatan Martapura, maka peneliti tertarik untuk melakukan suatu penelitian tentang Pengelolaan Buku Administrasi Desa di Kantor Pambakal Sungai Sipai Desa Sungai Sipai Kecamatan Martapura Kabupaten Banjar (Berdasarkan Peraturan Menteri Dalam Negeri Republik Indonesia Nomor 47 Tahun 2016 Tentang Administrasi Pemerintahan Desa). 


\section{TINJAUAN PUSTAKA}

\section{Pengertian Pengelolaan}

Pengelolaan adalah kegiatan kegiatan pemanfaatan dan pengendalian atas semua sumber daya yang diperlukan untuk mencapai ataupun menyelesaikan tujuan tertentu. Menurut Purwanto (2009) menjelaskan, Pengelolaan adalah serangkaian kegiatan-kegiatan untuk mencapai sasaran-sasaran tertentu dengan menggunakan orang-orang sebagai pelaksanaannya. Selanjutnya menurut Balderton dalam Adisasmita (2011) menjelaskan, istilah pengelolaan sama dengan manajemen yaitu menggerakkan, mengorganisasikan, dan mengarahkan usaha manusia untuk memanfaatkan secara material dan fasilitas untuk mencapai suatu tujuan. Sedangkan Adisasmita (2011) mengemukakan bahwa, Pengelolaan bukan hanya melaksanakan suatu kegiatan, akan tetapi merupakan rangkaian kegiatan yang meliputi fungsi-fungsi manajemen, seperti perencanaan, pelaksanaan, dan pengawasan untuk mencapai tujuan secara efektif dan efesien.

\section{Perencanaan}

Perencanaan merupakan bagian yang sangat penting dari pengelolaan dalam usaha untuk mencapai suatu tujuan. Perencanaan dibuat untuk mengantisipasi segala hal yang akan mengganggu atau menghalangi pencapaian tujuan, hal ini dikarenakan banya faktor yang akan berubah dengan cepat pada masa yang akan datang. Sehingga dengan adanya perencanaanyang baik akan membuat setiap kesempatan yang ada dapat dimanfaatkan dengan baik pula.

2. Pelaksanaan

Menurut Tjokroaminoto dalam Adisasmita (2011) mengemukakan bahwa, Pelaksanaan sebagai proses dapat kita pahami dalam bentuk rangkaian kegiatan yakni berawal dari kebijakan guna mencapai suatu tujuan maka kebijakan itu diturunkan dalam suatu program atau proyek. Selanjutnya Westra, dkk dalam
Adisasmita (2011) mengemukakan, Pengertian pelaksanaan sebagai usahausaha yang dilakukan untuk melaksanakan semua rencana dan kebijaksanaan yang telah dirumuskan dan ditetapkan dengan melengkapi segala kebutuhan alat-alat yang diperlukan, siapa yang akan melaksanakan, dimana tempat pelaksanaannya, dan kapan waktu dimulainya.

3. Pengawasan

Pengawasan atau pengendalian diperlukan mejamin bahwa bahwa rencana yang ditetapkan telah dilaksanakan sesuai dengan semestinya dan juga menilai apakah menyimpang atau sesuai degan rencana. Menurut Siswanto (2009) menjelaskan bahwa, Pengendalian berusaha untuk mengevaluasi apakah tujuan dapat dicapai, dan apabila tidak dapat dicapai maka dicari faktor penyebabnya. Penemuan faktor penyebab ini berguna untuk melakukan tindakan perbaikan. Selanjutnya Sujamto dalam Adisasmita (2011) mengemukakan bahwa, Pengawasan sebagai usaha atau kegiatan untuk mengetahui dan menilai kenyataan-kenyataan yang sebenarnya dan semestinya.

Dari beberapa penjelasan diatas dapat dismpulkan, pengertian pengelolaan pada penilitian ini adalah serangkaian proses atau kegiatan yang meliputi perencanaan, pelaksanaan (pengorganisasian dan pengarahan), dan pengawasan atau pengendalian.Fungsi yang dijalankan pada administrasi kantor tersebut sangat mendekati dengan fungsi-fungsi dalam teori sebelumnya. Hal ini dapat dilihat dari adanya pengelolaan surat-menyurat yang merupakan petunjuk pelaksanaan sumber daya yang ada pada karyawan sehari-hari.

\section{Pengertian Administrasi Desa}

Administrasi Desa adalah keseluruhan proses kegiatan pencatatan data dan informasi mengenai penyelenggaraan pemerintahan desa 
pada buku administrasi desa. Administrasi Desa adalah keseluruhan proses kegiatan penyelenggaraan pemerintahan da pembangunan dengan memanfaatkan kemampuan aparat desa serta segala sumber yang ada untuk mencapai tujuan yang ditetapkan yaitu terwujudnya peningkatan partisipasi dalam pemerintahan dan pembangunan serta penyelenggaraan administrasi yang makin meluas dan efektif.

Dari penjelasan diatas dapat disimpulkan bahwa administrasi desa adalah proses kegiatan pencatatan data dan informasi mengenai penyelenggaraan pemerintahan desa pada buku administrasi desa. Administrasi desa ditetapkan dengan Keputusan Menteri Dalam Negeri tapi teknis pelaksanaan dan pembinaan operasionalnya ditetapkan dengan keputusan Bupati.

\section{Model Buku Administrasi Desa}

\section{Buku Administrasi Umum}

Administrasi Umum adalah kegiatan pencatatan data dan informasi mengenai kegiatan-kegiatan Pemerintahan Desa dimuat dalam buku Administrasi Umum. Administrasi Umum meliputi :

a. Buku Data Peraturan Desa.

b. Buku Data Keputusan Kepala Desa.

c. Buku Data Inventaris Desa.

d. Buku Data Aparat Pemerintah Desa.

e. Buku Data Tanah Milik Desa/Tanah Kas Desa.

f. Buku Data Tanah Desa.

g. Buku Agenda.

h. Buku Ekspedisi.

\section{Buku Administrasi Penduduk}

Administrasi adalah Penduduk adalah kegiatan pencatatan data dan informasi mengenai kependudukan di desa baik mengenai penduduk sementara, penambahan, dan pengurangan penduduk maupun perkembangan penduduk dimuat dalam administrasi penduduk di desa. Administrasi Penduduk meliputi :
a. Buku Data Induk Penduduk.
b. Buku Data Mutasi Penduduk.
c. Buku Data Rekapitulasi Jumlah Penduduk Akhir Bulan.
d. Buku Data Penduduk Sementara.

\section{Buku Administrasi Keuangan}

Administrasi Keuangan Desa adalah kegiatan pencatatan data dan informasi mengenai pengelolaan keuangan desa dimuat dalam administrasi keuangan di desa. Administrasi Keuangan meliputi :

a. Buku Anggaran Penerimaan.

b. Buku Anggaran Pengeluaran Rutin.

c. Buku Anggaran Pengeluaran Pembangunan.

d. Buku Kas Umum.

e. Buku Kas Pembantu Penerimaan.

f. Buku Kas Pembantu Pengeluaran Rutin.

g. Buku Kas Pembantu Pengeluaran Pembangunan.

\section{Buku Administrasi Pembangunan}

Administrasi Pembangunan adalah kegiatan pencatatan data dan informasi mengenai pelaksanaan pembangunan dan pemberdayaan masyarakat yang akan, sedang, dan telah dilaksanakan dimuat dalam administrasi pembangunan di desa. Administrasi Pembangunan meliputi :
a. Buku Rencana Pembangunan.
b. Buku Kegiatan Pembangunan.
c. Buku Inventaris Proyek.
d. Buku Kader-Kader Pembangunan.

\section{Buku Administrasi Badan Permusya- waratan Desa}

Administrasi Badan Permusyawaratan Desa (BPD) atau yang disebut dengan BPD adalah kegiatan pencatatan data dan informasi mengenai BPD, terdiri dari:
a. Buku Data Anggota BPD.
b. Buku Data Keputusan BPD.
c. Buku Data Kegiatan BPD.
d. Buku Agenda BPD.
e. Buku Ekspedisi BPD.

\section{Buku Administrasi Lainnya}

Administrasi lainnya adalah kegiatan pencatatan data dan informasi mengenai penyelenggaraan pemerintahan desa, pelaksnaan pembangunan, pemberdayaan masyarakat, dan hubungan masyarakat. Dengan demikian maka akan terlihat bahwa administrasi itu meliputi seluruh kegiatan penyelenggaraan pemerintahan 
desa, pelaksanaan pembangunan, pemberdayaan masyarakat, dan hubungan masyarakat.

\section{METODE PENELITIAN}

Penelitian ini dilakukan dengan cara observasi langsung ke lokasi penelitian yaitu di Kantor Pambakal Sungai Sipai Desa Sungai Sipai Kecamtan Martapura. Pendekatan penelitian yang digunakan adalah pendekatan kualitatif, yaitu data yang diperoleh disusun berdasarkan pada hasil penelitian dengan jalan mengumpulkan data dan informasi yang diperoleh di lapangan untuk mendapatkan gambaran yang lebih jelas tentang objek penelitian yang dimaksud.

Informan dalam penelitian ini adalah aparatur pemerintah desa di Kantor Pambakal Sungai Sipai Desa Sungai Sipai Kecamatan Martapura Kabupaten Banjar. Untuk penggalian data primer peneliti menggali informasi melalui Kepala Urusan Pemerintahan, Kepala Urusan Pembangunan, dan Bendahara Desa.

Selanjutnya data yang sudah terkumpul akan dianalisis melalui diskriptif kualitatif yang dimaksudkan untuk menggambarkan permasalahan sesuai dengan sasaran dan tujuan penelitian serta akan diperoleh gambaran yang sejelas-jelasnya.

\section{HASIL DAN PEMBAHASAN}

Berdasarkan rumusan masalah yang peneliti buat maka dalam hasil penelitian ini menjelaskan tentang bagaimana pengelolaan buku administrasi desa di Kantor Pambakal Sungai Sipai Desa Sungai Sipai Kecamatan Martapura Kabupaten Banjar sesuai dengan Permendagri No. 47 tahun 2016, dilihat dari segi cara pengelolaan. Dalam mengumpulkan informasi dan data tersebut, peneliti telah melakukan wawancara dengan beberapa aparat desa yang terkait dengan pengelolaan buku administrasi desa ini yaitu Kaur Pemerintahan, Kaur Pembangunan, dan Bendahara Desa.

\section{A. Pengelolaan Buku Administrasi Umum}

Pengelolaan Buku Administrasi Umum merupakan kegiatan pengorganisasian buku- buku administrasi umum dalam tertib administrasi desa untuk mencapai sasaran atau tujuan. Dari hasil wawancara yang peneliti lakukan dengan Bapak Yusya, selaku Kepala Urusan Pemerintahan mengenai Administrasi Umum menerangkan bahwa:

Saya mulai menjabat sebagai Kepala Urusan Pemerintahan dari tahun 2009 sampai sekarang. Administrasi yang dulu kurang tertib, namun sekarang sudah tertib dan terorganisasi. Pengelolaan buku administrasi umum harus dipelihara, kalau ada pemerikasaan bisa dicek langsung.

Administrasi Umum adalah kegiatan pencatatan data dan informasi mengenai kegiatan pemerintahan desa. Buku Administrasi Umum terdiri dari :

1. Buku Data Peraturan Desa.

2. Buku Data Keputusan Kepala Desa.

3. Buku Data Inventaris Desa.

4. Buku Data Aparat Pemerintah Desa.

5. Buku Data Tanah Milik Desa/Tanah Kas Desa.

6. Buku Data Tanah Desa.

7. Buku Agenda.

8. Buku Ekspedisi.

Buku administrasi umum yang dikelola oleh Kaur Pemerintahan Desa Sei Sipai Kecamatan Martapura Kabupaten Banjar ditemukan hasil sebagai berikut :

\section{Buku Data Peraturan Desa}

Pada Kantor Desa Sungai Sipai, Buku Data Peraturan Desa bersifat lengkap.

Cara Pengisian:

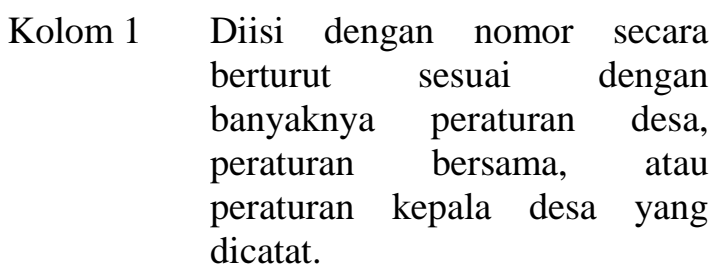

Kolom 2 Diisi dengan jenis peraturan di desa yaitu peraturan desa, peraturan bersama, atau peraturan kepala desa.

Kolom 3 Diisi dengan nomor dan 
tanggal, bulan, tahun ditetapkannya peraturan desa, peraturan bersama kepala desa, atau peraturan kepala desa.

Kolom 4 Diisi dengan judul/penamaan peraturan desa, peraturan bersama kepala desa, atau peraturan kepala desa.

Kolom 5 Diisi secara jelas dan singkat tentang materi pokok pada peraturan desa, peraturan bersama kepala desa, atau peraturan kepala desa yang telah ditetapkan.

Kolom 6 Diisi tanggal, bulan, dan tahun dari kesepakatan pemerintah desa dan BPD (khusus untuk peraturan desa).

Kolom 7 Diisi dengan nomor surat pengantar dan tanggal, bulan dan tahun pelaporan kepada Bupati/Walikota.

Kolom 8 Diisi dengan tanggal dan nomor sesuai dengan diundangkannya dalam lembaran desa.

Kolom 9 Diisi dengan tanggal dan nomor sesuai dengan diundangkannya dalam berita desa.

Kolom 10 Diisi dengan catatan-catatan lain yang dianggap perlu

\section{Buku Data Keputusan Kepala Desa}

Pada Kantor Desa Sungai Sipai, Buku Data

Keputusan Kepala Desa bersifat lengkap.

Cara pengisian:

Kolom 1 Diisi dengan nomor secara berturut sesuai dengan banyaknya Keputusan kepala desa yang dicatat.

Kolom 2 Diisi dengan nomor dan tanggal, bulan, tahun dari keputusan kepala desa.

Kolom 3 Diisi dengan judul/penamaan keputusan kepala desa.

Kolom 4 Diisi secara jelas dan singkat tentang materi pokok pada keputusan kepala desa yang dicatat.

Kolom 5 Diisi dengan nomor surat pengantar dan tanggal, bulan dan tahun pelaporan kepada Bupati/Walikota.

Kolom 6 Diisi dengan catatan-catatan lain yang dianggap perlu.

\section{Buku Data Invetaris Desa}

Pada Kantor Desa Sungai Sipai, Buku Data

Inventaris Desa bersifat tidak lengkap.

\section{Buku Aparat Pemerintah Desa}

Pada Kantor Desa Sungai Sipai, Buku Aparat Pemerintah Desa bersifat lengkap.

Cara pengisian:

Kolom 1 Diisi dengan nomor secara berurut sesuai dengan jumlah Aparat Pemerintahan Desa termasuk anggota BPD.

Kolom 2 Diisi dengan nama lengkap.

Kolom 3 Diisi dengan Nomor Induk Aparat Pemerintah Desa bagi perangkat desa yang bukan berasal dari Pegawai Negeri Sipil.

Kolom 4 Diisi dengan Nomor Induk Pegawai (NIP) bagi aparat Pemerintahan Desa yang berasal dari Pegawai Negeri Sipil.

Kolom 5 Diisi dengan jenis kelamin, L (untuk Laki-Laki), dan P (untuk Perempuan).

Kolom 6 Diisi dengan tempat lahir, tanggal, bulan, dan tahun kelahiran.

Kolom 7 Diisi dengan Agama dan Kepercayaan.

Kolom 8 Diisi dengan pangkat/golongan aparat desa bagi Pegawai Negeri Sipil.

Kolom 9 Diisi dengan nama jabatan masing-masing Perangkat Desa dan anggota BPD.

Kolom 10 Diisi dengan pendidikan formal terakhir.

Kolom 11 Diisi dengan nomor, tanggal, bulan, dan tahun keputusan Pengangkatan perangkat desa dan anggota BPD.

Kolom 12 Diisi dengan nomor, tanggal, 
bulan, dan tahun keputusan pemberhentian.

Kolom 13 Diisi dengan catatan-catatan lain yang dianggap perlu.

\section{Buku Data Tanah Milik Desa/Tanah Kas Desa \\ Pada Kantor Desa Sungai Sipai, Buku Data Tanah Milik Desa/Tanah Kas Desa bersifat tidak lengkap.}

\section{Buku Data Tanah Desa}

Pada Kantor Desa Sungai Sipai, Buku Data Tanah Desa bersifat lengkap.

Cara pengisian:

Kolom 1 Diisi dengan nomor secara berurut sesuai dengan jumlah tanah di desa.

Kolom 2 Diisi dengan nama pemilik/ pemegang hak atas tanah.

Kolom 3 Diisi dengan luas tanah dalam meter persegi $\left(\mathrm{m}^{2}\right)$

Kolom 4 Diisi dengan luas tanah yang bersertifikat dengan status sebagai Hak Milik.

Kolom 5 Diisi dengan luas tanah yang bersertifikat dengan status sebagai Hak Guna Bangunan.

Kolom 6 Diisi dengan luas tanah yang bersertifikat dengan status sebagai Hak pakai.

Kolom 7 Diisi dengan luas tanah yang bersertifikat dengan status sebagai Hak Guna Usaha.

Kolom 8 Diisi dengan luas tanah yang bersertifikat dengan status sebagai Hak Pengelolaan.

Kolom 9 Diisi dengan luas tanah yang bersertifikat dengan status sebagai Hak Milik Adat.

Kolom 10 Diisi dengan luas tanah yang bersertifikat dengan status sebagai Hak Verponding Indonesia (milik pribumi).

Kolom 11 Diisi dengan luas tanah yang bersertifikat dengan status sebagai Tanah Negara.

Kolom 12 Diisi dengan luas tanah non pertanian yang penggunaannya untuk perumahan.

Kolom 13 Diisi dengan luas tanah non pertanian yang penggunaannya untuk perdagangan dan jasa.

Kolom 14 Diisi dengan luas tanah non pertanian yang penggunaannya untuk perkantoran.

Kolom 15 Diisi dengan luas tanah non pertanian yang penggunaannya untuk usaha industri.

Kolom 16 Diisi dengan luas tanah non pertanian yang penggunaannya untuk fasilitas umum.

Kolom 17 Diisi dengan luas tanah pertanian yang penggunaannya untuk sawah baik yang beririgasi maupun non irigasi.

Kolom 18 Diisi dengan luas tanah pertanian yang penggunaannya untuk tegalan.

Kolom 19 Diisi dengan luas tanah pertanian yang penggunaannya untuk perkebunan.

Kolom 20 Diisi dengan luas tanah pertanian yang penggunaannya untuk peternakan/perikanan.

Kolom 21 Diisi dengan luas tanah pertanian yang penggunaannya untuk hutan belukar yang dapat dibuka usaha pertanian.

Kolom 22 Diisi dengan luas tanah pertanian yang penggunaannya untuk hutan lebat/lindung sebagai sumber air dan kelestarian alam.

Kolom 23 Diisi setiap terjadi mutasi tanah di desa.

Kolom 24 Diisi dengan luas tanah pertanian yang penggunaannya untuk tanah kosong yang ditelantarkan.

Kolom 25 Diisi dengan luas tanah pertanian yang penggunaannya untuk lain-lain.

Kolom 26 Diisi dengan catatan-catatan lain yang dianggap perlu.

\section{Buku Agenda}

Pada Kantor Desa Sungai Sipai, Buku Agenda bersifat lengkap. 
Cara pengisian:

Kolom 1 Diisi dengan nomor secara berurut sesuai dengan urutan surat masuk dan keluar.

Kolom 2 Diisi dengan tanggal diterimanya surat atau tanggal pengiriman surat.

Kolom 3 Diisi dengan nomor surat masuk.

Kolom 4 Diisi dengan tanggal, bulan dan tahun surat masuk.

Kolom 5 Diisi dengan nama instansi pengirim surat masuk.

Kolom 6 Diisi dengan perihal surat masuk.

Kolom 7 Diisi dengan nomor surat keluar.

Kolom 8 Diisi dengan tanggal, bulan dan tahun surat keluar.

Kolom 9 Diisi dengan nama instansi yang dituju.

Kolom 10 Diisi dengan perihal surat keluar.

Kolom 11 Diisi dengan catatan-catatan lain yang dianggap perlu.

\section{Buku Ekspedisi}

Pada Kantor Desa Sungai Sipai, Buku Ekspedisi bersifat lengkap.

Cara pengisian:

Kolom 1 Diisi dengan nomor secara berurut sesuai dengan surat yang dikirim.

Kolom 2 Diisi dengan tanggal, bulan dan tahun surat dikirim.

Kolom 3 Diisi dengan tanggal, bulan, tahun dan nomor surat dikirim.

Kolom 4 Diisi dengan perihal surat yang dikirim.

Kolom 5 Diisi dengan nama pihak yang dituju.

Kolom 6 Diisi dengan catatan-catatan lain yang dianggap perlu.

Dari 8 model buku administrasi umum diatas hanya terdapat 6 model buku yang dimiliki dan dikelola oleh bidang KAUR Pemerintahan, yaitu : 1) Buku Data Peraturan Desa, 2) Buku Data Keputusan Kepala Desa, 3)
Buku Data Aparat Pemerintah Desa, 4) Buku Data Tanah Desa, 5) Buku Agenda, dan 6) Buku Ekspedisi. 2 model buku administrasi umum yang tidak dimiliki oleh Kantor Pambakal Sungai Sipai adalah Buku Data Inventaris Desa dan Buku Data Tanah Milik Desa/Tanah Kas Desa.

Kantor Pambakal Sungai Sipai tidak memiliki Buku Data Inventaris Desa, karena pengurusan dan pengawasan yang kurang efektif terhadap barang-barang milik Negara maupun milik Swasta. Kantor pambakal Sungai Sipai juga tidak memiliki Buku Data Tanah Milik Desa/Tanah Kas Desa, karena tidak memiliki tanah yang berasal dari kekayaan asli desa, dibeli atau diperoleh atas beban Anggaran Pendapatan dan Belanja Desa (APBD) atau perolehan hak lainnya yang sah.

\section{B. Pengelolaan Buku Administrasi Penduduk Desa}

Pengelolaan Buku Administrasi Penduduk adalah serangkaian kegiatan pencatatan data pada buku-buku administrasi penduduk agar penduduk desa setempat dapat terdata dengan baik dan benar sesuai dengan jumlah penduduknya. Dari hasil wawancara yang peneliti lakukan dengan Bapak Yusya, selaku Kepala Urusan Pemerintahan mengenai Administrasi Penduduk menyebutkan bahwa:
Administrasi desa menurutkulah dalam mengatur dan mengurus kepentingan masyarakat setempat berdasarkan keperluan warga desa sungai sipai sini. Pengelolaan buku administrasi penduduk dalam pencatatan data penduduk yang tinggal di desa ini baik sementara atau pindahan. Hambatannya dalam mengelola buku administrasi penduduk masalah kependudukan banyak warga pendatang yang tidak melapor pas di data baru ketahuan, waktu ada keperluan baru melapor. Harapanku RT lebih aktif, lebih bisa mensosialisasikan kependudukan.

Administrasi Penduduk adalah kegiatan pencatatan data dan informasi mengenai kependudukan di desa baik mengenai penduduk 
sementara, penambahan, dan pengurangan penduduk maupun perkembangan penduduk di desa. Buku Administrasi Penduduk Desa terdiri dari:

1. Buku Data Induk Penduduk.

2. Buku Data Mutasi Penduduk.

3. Buku Data Rekapitulasi Jumlah Penduduk Akhir Bulan.

4. Buku Data Penduduk Sementara.

Buku administrasi penduduk yang dimiliki dan dikelola oleh bidang KAUR Pemerintahan serta lengkap dan tidak lengkapnya buku administrasi penduduk tersebut, yaitu :

\section{Buku Data Induk Penduduk}

Pada Kantor Desa Sungai Sipai, Buku Data Induk Penduduk bersifat lengkap.

Cara pengisian:

Kolom 1 Diisi dengan nomor secara berurutan dari nomor 1 (satu), dan seterusnya sesuai dengan jumlah kartu keluarga setiap kepala keluarga disediakan satu halaman dan diiisi secara berurut berdasarkan kartu keluarga yang sudah diisi oleh kepala keluarga.

Kolom 2 Diisi dengan nama lengkap dan atau kalau ada disebutkan nama Panggilan.

Kolom 3 Diisi dengan huruf L (untuk Laki-Laki), dan $\mathrm{P}$ (untuk Perempuan).

Kolom 4 Diisi dengan Status Perkawinan yaitu K yang sudah Kawin, BK yang Belum Kawin, JD Janda, DD Duda.

Kolom 5 Diisi dengan tempat lahir yakni nama Desa, Kecamatan, Kabupaten/Kota, dimana yang bersangkutan dilahirkan.

Kolom 6 Diisi dengan tanggal, bulan dan tahun kelahiran yang bersangkutan.

Kolom 7 Diisi sesuai dengan Agama dan Kepercayaan.

Kolom 8 Diisi dengan Pendidikan terakhir baik formal maupun informal.

Kolom 9 Diisi dengan jenis pekerjaan.

Kolom 10 Diisi dengan huruf L (bagi yang dapat membaca huruf latin), D (Daerah), A (Arab), AL (Arab dan Latin), AD (Arab dan Daerah), dan ALD (Arab, Latin, Daerah).

Kolom 11 Diisi dengan Kewarganegaraan (WNI atau WNA).

Kolom 12 Diisi dengan alamat lengkap.

Kolom 13 Diisi dengan KK (Kepala Keluarga), Ist (Istri), AK (Anak Kandung), AA (Anak Angkat), Pemb (Pembantu).

Kolom 14 Diisi dengan Nomor Induk Kependudukan.

Kolom 15 Diisi dengan nomor Kartu Keluarga.

Kolom 16 Diisi dengan catatan-catatan lain yang dianggap perlu.

\section{Buku Data Mutasi Penduduk}

Pada Kantor Desa Sungai Sipai, Buku Data Mutasi Penduduk bersifat lengkap.

Cara pengisian:

Kolom 1 Diisi dengan nomor secara berurutan dari nomor 1 (satu), dan seterusnya sesuai dengan urutan mutasi/ perubahan penduduk.

Kolom 2 Diisi dengan nama lengkap dan kalau ada disebutkan nama panggilan yang bersangkutan.

Kolom 3 Diisi dengan tempat lahir yakni nama Desa, Kecamatan, Kabupaten/Kota, dimana yang bersangkutan dilahirkan.

Kolom 4 Diisi dengan tanggal, bulan dan tahun kelahiran yang bersangkutan.

Kolom 5 Diisi dengan huruf L (untuk Laki-Laki), dan $\mathrm{P}$ (untuk Perempuan).

Kolom 6 Diisi dengan Kewarganegaraan (WNI atau WNA).

Kolom 7 Diisi dengan asal tempat dan alamat semula dari penduduk yang baru datang. 
Kolom 8 Diisi dengan tanggal, bulan, dan tahun kedatangan dari penduduk yang baru ke Desa dimaksud.

Kolom 9 Diisikan dengan lokasi tujuan pindah.

Kolom 10 Diisikan dengan tanggal, bulan, dan tahun kepindahan sesuai dengan surat keterangan pindah.

Kolom 11 Diisikan dengan tempat meninggal dari orang tersebut.

Kolom 12 Diisikan dengan tanggal, bulan, dan tahun atas meninggalnya orang tersebut.

Kolom 13 Diisi dengan catatan-catatan lain yang dianggap perlu.

\section{Buku Data Rekapitulasi Jumlah Penduduk Akhir Bulan \\ Pada Kantor Desa Sungai Sipai, Buku Data Rekapitulasi Akhir Bulan bersifat lengkap. \\ Cara pengisian:}

Kolom 1 Diisi dengan nomor secara berurutan dari nomor 1, dan seterusnya sesuai dengan jumlah dusun/lingkungan di Desa yang bersangkutan.

Kolom 2 Diisi dengan nama dusun atau wilayah bagian Desa dari Desa yang bersangkutan.

Kolom 3 Diisi dengan jumlah laki-laki dari Warga Negara Asing.

Kolom 4 Diisi dengan jumlah perempuan dari Warga Negara Asing.

Kolom 5 Diisi dengan jumlah laki-laki dari Warga Negara Indonesia.

Kolom 6 Diisi dengan jumlah perempuan Warga Negara Indonesia.

Kolom 7 diisi dengan jumlah kepala keluarga.

Kolom 8 Diisi dengan jumlah anggota keluarga.

Kolom 9 Diisi jumlah jiwa/penduduk dengan cara menambahkan jumlah pada kolom (7) dan kolom (8).

Kolom 10 Diisi dengan jumlah tambahan laki-laki karena lahir dari Warga Negara Asing.

Kolom 11 Diisi dengan jumlah tambahan perempuan karena lahir dari Warga Negara Asing.

Kolom 12 Diisi dengan jumlah tambahan laki-laki karena lahir dari Warga Negara Indonesia.

Kolom 13 Diisi dengan jumlah tambahan perempuan karena lahir dari Warga Negara Indonesia.

Kolom 14 Diisi dengan jumlah tambahan laki-laki dari Warga Negara Asing yang datang/pindah ke desa tersebut.

Kolom 15 Diisi jumlah tambahan perempuan bagi Warga Negara Asing yang datang/pindah ke desa tersebut.

Kolom 16 Diisi dengan jumlah tambahan laki-laki dari warga Negara Indonesia yang datang/pindah ke desa tersebut.

Kolom 17 Diisi dengan jumlah tambahan perempuan dari Warga Negara

Indonesia yang datang/pindah ke desa tersebut.

Kolom 18 Diisi dengan jumlah laki-laki yang kurang karena meninggal dari Warga Negara Asing.

Kolom 19 Diisi dengan jumlah perempuan yang kurang karena meninggal dari Warga Negara Asing.

Kolom 20 Diisi dengan jumlah laki-laki yang kurang karena meninggal dari Warga Negara Indonesia.

Kolom 21 Diisi dengan jumlah perempuan yang kurang karena meninggal dari Warga Negara Indonesia.

Kolom 22 Diisi dengan jumlah laki-laki yang pindah dari Warga Negara Asing.

Kolom 23 Diisi dengan jumlah perempuan yang pindah dari Warga Negara Asing.

Kolom 24 Diisi dengan jumlah laki-laki yang pindah dari Warga Negara Indonesia.

Kolom 25 Diisi dengan jumlah perempuan yang pindah dari Warga Negara Indonesia

Kolom 26 Diisi dengan jumlah laki-laki dari Warga Negara Asing. 
Kolom 27 Diisi dengan jumlah perempuan dari Warga Negara Asing.

Kolom 28 Diisi dengan jumlah laki-laki dari Warga Negara Indonesia.

Kolom 29 Diisi dengan jumlah perempuan dari Warga Negara Indonesia.

Kolom 30 Diisi dengan jumlah kepala keluarga.

Kolom 31 Diisi dengan jumlah anggota keluarga.

Kolom 32 Diisi dengan jumlah jiwa dengan cara menambahkan jumlah pada kolom (30) dan kolom (31).

Kolom 33 Diisi dengan catatan-catatan lain yang dianggap perlu.

\section{Buku Data Penduduk Sementara}

Pada Kantor Desa Sungai Sipai, Buku Data Penduduk Sementara bersifat lengkap.

Cara pengisian:

Kolom 1 Diisi dengan nomor secara berurutan dari nomor 1, dan seterusnya sesuai dengan jumlah penduduk sementara.

Kolom 2 Diisi dengan nama lengkap tamu yang bersangkutan.

Kolom 3 Diisi dengan huruf L (untuk Laki-Laki).

Kolom 4 Diisi dengan huruf $\mathrm{P}$ (untuk Perempuan).

Kolom 5 Diisi dengan nomor identitas atau tanda pengenal dari tamu yang bersangkutan.

Kolom 6 Diisi dengan nama desa dan kecamatan serta Kabupaten/ Kota tempat yang bersangkutan dilahirkan dan tanggal, bulan dan tahun kelahiran yang bersangkutan.

Kolom 7 Diisi sesuai dengan pekerjaan yang bersangkutan. Misalnya PNS (Pegawai Negeri Sipil), TNI/POLRI, karyawan, buruh, nelayan, mahasiswa dan lain sebagainya, kalau belum mempunyai pekerjaan diberi tanda strip (-).

Kolom 8 Diisi dengan WNl bagi penduduk asli Warga Negara Indonesia.

Kolom 9 Diisi dengan nama negara asalnya, WNA bagi penduduk Warga Negara Asing.

Kolom 10 Diisi dengan lokasi/tempat kedatangan/asal tamu yang bersangkutan.

Kolom 11 Diisi dengan maksud dan tujuan kedatangan tamu yang bersangkutan.

Kolom 12 Diisi dengan nama dan alamat yang dikunjungi di desa yang bersangkutan.

Kolom 13 Diisi dengan tanggal kedatangan di desa yang bersangkutan.

Kolom 14 Diisi dengan tanggal kepergian/kepulangan tamu yang bersangkutan.

Kolom 15 Diisi dengan catatan-catatan lain yang dianggap perlu.

Dari 4 model buku administrasi penduduk di atas yang dimiliki dan dikelola oleh bidang KAUR Pemerintahan adalah lengkap. Akan tetapi, dalam pengelolaan Buku Administrasi Penduduk masih terdapat hambatan yaitu, masalah kependudukan banyak warga yang tidak melapor setelah diadakan pendataan penduduk sehingga ketika ada keperluan penduduk akan melapor kepada Aparat Pemerintah Desa setempat dan baru diketahui keberadaannya.

\section{Pengelolaan Buku Administrasi Keuangan}

Pengelolaan Buku Administrasi Keuangan ialah kegiatan pencatatan data mengenai anggaran-anggaran dana desa berdasarkan kebutuhan yang diperlukan dan sesuai dengan pembukuan yang telah ditentukan. Dari hasil wawancara yang peneliti lakukan dengan Ibu Normini, selaku Bendahara mengenai Administrasi Keuangan menerangkan bahwa:

Aku menjabat jadi bendahara sekitar kurang lebih 7 tahun. Pengelolaan buku administrasi keuangan aku mengatur lawan mengelola keuangan desa. Hambatannya banyak tugas-tugas yang diserahkan. Harapan mudahan kawa 
menggawi,bisa aja yang digawi sesuai dengan prosedur.

Administrasi Keuangan adalah kegiatan pencatatan data dan informasi mengenai pengelolaan keuangan desa. Buku administrasi keuangan terdiri dari:

1. Buku Anggaran Penerimaan.

2. Buku Anggaran Pengeluaran Rutin.

3. Buku Anggaran Pengeluaran Pembangunan.

4. Buku Kas Umum.

5. Buku Kas Pembantu Penerimaan.

6. Buku Kas Pembantu Pengeluaran Rutin.

7. Buku Kas Pembantu Pengeluaran Pembangunan.

Buku administrasi keuangan yang dimiliki dan dikelola oleh Bendahara serta lengkap dan tidak lengkapnya buku administrasi penduduk tersebut, yaitu :

\section{Buku Anggaran Penerimaan}

Pada Kantor Desa Sungai Sipai, Buku Anggaran Penerimaan bersifat lengkap.

Cara pengisian:

Kolom 1 Diisi dengan kode rekening berdasarkan klasifikasi kelompok belanja desa.

Kolom 2 Diisi dengan uraian sesuai urutan kegiatan dalam APB Desa.

Kolom 3 Diisi dengan anggaran berdasarkan kegiatan dalam APB Desa.

Kolom 4 Diisi dengan catatan-catatan lain yang dianggap perlu.

\section{Buku Anggaran Pengeluaran Rutin}

Pada Kantor Desa Sungai Sipai, Buku Anggaran Pengeluaran Rutin bersifat lengkap.

Cara pengisian:

Kolom 1 Diisi dengan nomor urut.

Kolom 2 Diisi dengan uraian berupa rincian kebutuhan dalam kegiatan.

Kolom 3 Diisi dengan volume dapat berupa jumlah orang/barang.

Kolom 4 Diisi dengan harga satuan yang merupakan besaran untuk membayar Orang/barang.

Kolom 5 Diisi dengan jumlah perkalian antara kolom 3 dengan kolom 4 .

\section{Buku Anggaran Pengeluaran Pemba- ngunan}

Pada Kantor Desa Sungai Sipai, Buku Anggaran Pengeluaran Pembangunan bersifat Tidak lengkap.

4. Buku Kas Umum

Pada Kantor Desa Sungai Sipai, Buku Kas Umum bersifat lengkap.

Cara Pengisian:

Kolom 1 Diisi dengan nomor urut penerima kas atau pengeluaran kas.

Kolom 2 Diisi dengan tanggal penerimaan kas atau pengeluaran kas.

Kolom 3 Diisi dengan kode rekening penerimaan kas atau pengeluaran kas.

Kolom 4 Diisi dengan uraian transaksi penerimaan kas atau pengeluaran kas.

Kolom 5 Diisi dengan jumlah rupiah penerimaan kas.

Kolom 6 Diisi dengan jumlah rupiah pengeluaran kas.

Kolom 7 Diisi dengan nomor bukti transaksi.

Kolom 8 Diisi dengan penjumlahan komulatif pengeluaran kas.

Kolom 9 Diisi dengan saldo kas.

\section{Buku Kas Pembantu Penerimaan}

Pada Kantor Desa Sungai Sipai, Buku Kas Pembantu Penerimaan bersifat lengkap.

Cara pengisian:

Kolom 1 Diisi dengan nomor urut penerimaan atau pengeluaran kas pengeluaran.

Kolom 2 Diisi dengan tanggal penerimaan atau pengeluaran 
kas pengeluaran.

Kolom 3 Diisi dengan uraian penerimaan pajak, retribusi, dan penerimaan lainnya.

Kolom 4 Diisi dengan uraian penerimaan pajak, retribusi, dan penerimaan lainnya.

Kolom 5 Diisi dengan uraian penerimaan pajak, retribusi, dan penerimaan lainnya.

Kolom 6 Diisi dengan jumlah rupiah penerimaan kas.

Kolom 7 Diisi dengan jumlah rupiah pengeluaran kas.

Kolom 8 Diisi dengan saldo buku kas bendahara.

\section{Buku Kas Pembantu Pengeluaran Rutin}

Pada Kantor Desa Sungai Sipai, Buku Kas Pembantu Pengeluaran Rutin bersifat lengkap.

Cara pengisian:

Kolom 1 Diisi dengan tanggal pengeluaran rutin sesuai dengan bukti pengeluaran uang.

Kolom 2 Diisi dengan uraian jenis pengeluaran sesuai dengan urutan jenis pengeluaran rutin yang terdapat dalam Buku Kas Umum

Kolom 3 Diisi dengan nomor bukti sesuai dengan yang tercantum dalam Buku Kas Umum sehubungan dengan pengekuaran uang pada tanggal yang bersangkutan.

Kolom 4 Diisi dengan jumlah pengeluaran untuk masingmasing pos/kode anggaran sesuai dengan uraian kegiatan pada kolom (2).

Kolom 5 Diisi dengan jumlah pengeluaran untuk masingmasing pos/kode anggaran sesuai dengan uraian kegiatan pada kolom (2).

Kolom 6 Diisi dengan jumlah pengeluaran untuk masingmasing pos/kode anggaran sesuai dengan uraian kegiatan pada kolom (2).

\begin{tabular}{|c|c|}
\hline lom 7 & $\begin{array}{l}\text { Diisi dengan } \\
\text { pengeluaran untuk masing- } \\
\text { masing pos/kode anggaran } \\
\text { sesuai dengan uraian kegiatan } \\
\text { pada kolom (2). }\end{array}$ \\
\hline olom 8 & $\begin{array}{l}\text { Diisi dengan } \\
\text { pengeluaran untuk masing- } \\
\text { masing pos/kode anggaran } \\
\text { sesuai dengan uraian kegiatan } \\
\text { pada kolom (2). }\end{array}$ \\
\hline olom 9 & $\begin{array}{l}\text { Diisi dengan } \\
\text { pengeluaran untuk masing- } \\
\text { masing pos/kode anggaran } \\
\text { sesuai dengan uraian kegiatan } \\
\text { pada kolom (2). }\end{array}$ \\
\hline 1 & $\begin{array}{l}\text { Diisi dengan jumlah } \\
\text { pengeluaran rutin dari masing- } \\
\text { masing pos setiap hari dan } \\
\text { selanjutnya dijumlahkan } \\
\text { kebawah dari keseluruhan } \\
\text { penerimaan yang ada. }\end{array}$ \\
\hline
\end{tabular}

\section{Buku Kas Pembantu Pengeluaran} Pembangunan

Pada Kantor Desa Sungai Sipai, Buku Kas Pembantu Pengeluaran Pembangunan bersifat lengkap.

Cara pengisian:

Kolom 1 Diisi dengan tanggal pengeluaran pembangunan sesuai dengan tanda bukti pengeluaran uang.

Kolom 2 Diisi dengan uraian jenis-jenis pengeluaran pembangunan sesuai dengan urutan jenis pengeluaran yang terdapat dalam Buku Kas Umum.

Kolom 3 Diisi dengan nomor bukti sesuai dengan yang tercantum dalam Buku Kas Umum sehubungan dengan pengeluaran uang pada tanggal yang bersangkutan

$\begin{array}{llr}\text { Kolom 4 } & \begin{array}{l}\text { Diisi dengan } \\ \text { pengeluaran untuk }\end{array} & \begin{array}{r}\text { jumlah } \\ \text { masing }\end{array} \\ & \text { masing pos/kode anggaran } \\ & \begin{array}{l}\text { sesuai dengan uraian } \\ \text { pegiatan }\end{array} \\ \text { Koda kolom (2). } & \\ \text { Kolom 5 } & \text { Diisi dengan } & \text { jumlah }\end{array}$


pengeluaran untuk masing masing pos/kode

anggaran sesuai dengan uraian kegiatan pada kolom (2).

Kolom 6 Diisi dengan jumlah pengeluaran untuk masing masing pos/kode anggaran sesuai dengan uraian kegiatan pada kolom (2).

Kolom 7 Diisi dengan jumlah pengeluaran untuk masing masing pos/kode anggaran sesuai dengan uraian kegiatan pada kolom (2).

Kolom 8 Diisi dengan jumlah pengeluaran untuk masing masing pos/kode anggaran sesuai dengan uraian kegiatan pada kolom (2).

Kolom 9 Diisi dengan jumlah pengeluaran untuk masing masing pos/kode anggaran sesuai dengan uraian kegiatan pada kolom (2).

Kolom 10 Diisi dengan jumlah pengeluaran pembangunan dari masing-masing pos setiap hari dan selanjutnya dijumlahkan kebawah dari keseluruhan penerimaan yang ada.

Dari 7 model Buku Administrasi Umum diatas hanya terdapat 6 model buku yang dimiliki dan dikelola oleh Bendahara, yaitu : 1) Buku Anggaran Penerimaan, 2) Buku Anggaran Pengeluaran Rutin, 3) Buku Anggaran Pengeluaran Pembangunan, 4) Buku Buku Kas Umum, 5) Buku Kas Pembantu Penerimaan, dan 6) Buku Kas Pembantu Pengeluaran Rutin. 1 model buku administrasi keuangan yang tidak dimiliki oleh Bendahara adalah Buku Anggaran Pengeluaran Pembangunan. Buku tersebut tidak dimiliki karena bendahara desa tidak mengelola pengeluaran keuangan pembangunan.

\section{Pengelolaan Buku Administrasi Pembangunan}

Pengelolaan Buku Administrasi Pembangunan adalah kegiatan mengenai proyek atau pembangunan-pembangunan yang dilakukan di desa agar desa tersebut menjadi desa yang terlihat lebih baik dan tertata dengan rapi. Dari hasil wawancara yang peneliti lakukan dengan Bapak Poniman, selaku Kepala Urusan Pembangunan mengenai Administrasi Pembangunan menerangkan bahwa:

Aku jadi KAUR Pembangunan kurang lebih 3 bulan. Administrasi desa yang $k u$ tau mengurusi masalah kependudukan, KTP, Kartu Keluarga, surat pindah, surat masuk, lawan data lahir. Pengelolaan Administrasi Pembangunan sudah sesuai dengan aturan Bupati. Hambatan tergantung pendanaan, penduduk/ masyarakat. Harapan supaya masyarakat itu bisa membuat administrasi lancar dan mensejahterakan masyarakat.

Administrasi Pembangunan adalah kegiatan pencatatan data dan informasi mengenai pelaksanaan pembangunan. Buku Administrasi Pembangunan terdiri dari:

1. Buku Rencana Pembangunan.

2. Buku Kegiatan Pembangunan.

3. Buku Inventaris Proyek.

4. Buku Kader-Kader Pembangunan.

Buku Administrasi Pembangunan yang dimiliki dan dikelola oleh KAUR Pembangunan serta lengkap dan tidak lengkapnya buku administrasi penduduk tersebut, yaitu :

\section{Buku Rencana Pembangunan}

Pada Kantor Desa Sungai Sipai, Buku Rencana Pembangunan bersifat lengkap.

Cara pengisian:

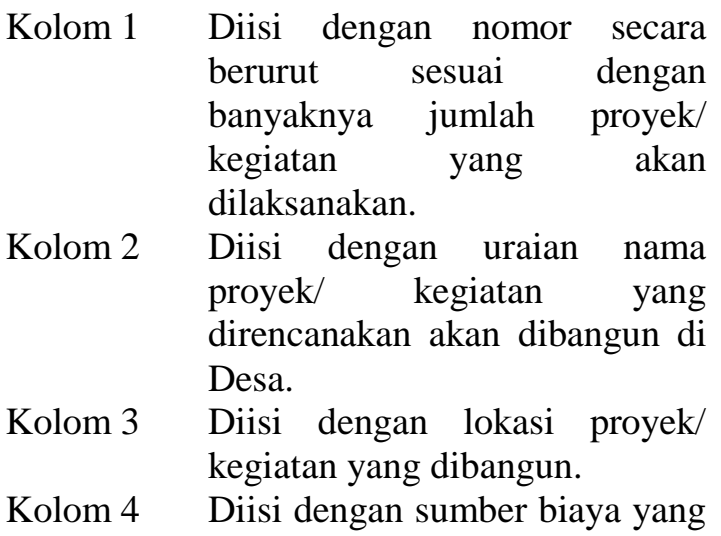


diperoleh dari Pemerintah untuk mendukung proyek/kegiatan dimaksud.

Kolom 5 Diisi dengan sumber biaya yang diperoleh dari Pemerintah Provinsi untuk mendukung proyek/kegiatan dimaksud.

Kolom 6 Diisi dengan sumber biaya yang diperoleh dari Pemerintah Kabupaten/ Kota untuk mendukung proyek/kegiatan dimaksud.

Kolom 7 Diisi dengan sumber biaya yang diperoleh dari swadaya masyarakat dan lembaga untuk mendukung proyek/kegiatan dimaksud.

Kolom 8 Diisi dengan besarnya jumlah keseluruhan biaya yang mendukung untuk kegiatan dimaksud baik dari sumber pemerintah hingga swadaya masyarakat.

Kolom 9 Diisi dengan pelaksana proyek/kegiatan dimaksud.

Kolom 10 Diisi dengan manfaat dari proyek/kegiatan yang akan dibangun.

Kolom 11 Diisi dengan catatan-catatan yang dianggap perlu.

\section{Buku Kegiatan Pembangunan}

Pada Kantor Desa Sungai Sipai, Buku Kegiatan Pembangunan bersifat lengkap.

Cara pengisian:

Kolom 1 Diisi dengan nomor urut nama proyek/kegiatan yang akan dilaksanakan.

Kolom 2 Diisi dengan uraian nama proyek/ kegiatan yang direncanakan akan dibangun di Desa.

Kolom 3 Diisi dengan besaran proyek/ kegiatan dimaksud.

Kolom 4 Diisi dengan sumber biaya yang diperoleh dari Pemerintah.

Kolom 5 Diisi dengan sumber biaya yang diperoleh dari Pemerintah Provinsi.
Kolom 6 Diisi dengan sumber biaya yang diperoleh dari Pemerintah

Kabupaten/Kota.

Kolom 7 Diisi dengan sumber biaya yang diperoleh dari swadaya masyakarat.

Kolom 8 Diisi dengan besarnya jumlah keseluruhan biaya yang mendukung yang diperoleh dari sumber Pemerintah hingga swadaya masyarakat.

Kolom 9 Diisi dengan waktu lamanya proyek/ kegiatan akan dilaksanakan.

Kolom 10 Diisi dengan sifat proyek/kegiatan yang akan dibangun merupakan proyek baru.

Kolom 11 Diisi dengan sifat proyek/kegiatan yang akan dibangun merupakan proyek lanjutan.

Kolom 12 Diisi dengan pelaksana proyek/kegiatan dimaksud.

Kolom 13 Diisi dengan catatan-catatan lain yang dianggap perlu.

\section{Buku Inventaris Proyek}

Pada Kantor Desa Sungai Sipai, Buku Invenrtaris Proyek bersifat lengkap.

Cara pengisian:

Kolom 1 Diisi dengan nomor urut nama jenis/hasil pembangunan yang telah dilaksanakan.

Kolom 2 Diisi dengan uraian atau nama proyek/kegiatan yang dibangun di Desa.

Kolom 3 Diisi dengan besaran proyek/ kegiatan.

Kolom 4 Diisi dengan besaran dukungan biaya atas proyek/kegiatan dimakud.

Kolom 5 Diisi dengan lokasi proyek/kegiatan yang dibangun.

Kolom 6 Diisi dengan catatan-catatan lain yang dianggap perlu. 
4. Buku Kader-Kader Pembangunan

Pada Kantor Desa Sungai Sipai, Buku Kader-

Kader Pembangunan bersifat lengkap.

Cara pengisian:

Kolom 1 Diisi dengan nomor urut nama kader pemberdayaan masyarakat.

Kolom 2 Diisi dengan nama kader yang ada di Desa.

Kolom 3 Diisi dengan umur kader tersebut.

Kolom 4 Diisi dengan huruf L (untuk Laki-Laki), dan $\mathrm{P}$ (untuk Perempuan).

Kolom 5 Diisi dengan pendidikan formal dan informal kader pemberdayaan masyarakat.

Kolom 6 Diisi dengan bidang keahlian yang ditekuni.

Kolom 7 Diisi dengan alamat lengkap.

Kolom 8 Diisi dengan catatan-catatan lain yang dianggap perlu.

Dari 4 model Buku Administrasi Pembangunan yang dimiliki dan dikelola oleh KAUR Pembangunan lengkap. Buku administrasi pembangunan dikelola dengan baik berdasarkan peraturan yang ditetapkan.

\section{E. Pengelolaan Buku Administrasi Badan Permusyawaratan Desa (BPD)}

Pengelolaan Buku Administrasi Badan Permusyawaratan Desa adalah kegiatan mengenai data-data yang bersangkutan dengan kepengurusan Badan Permusyawaratan Desa untuk mencapai tujuan. Dari hasil wawancara yang peneliti lakukan dengan Bapak Anang Samad, selaku Ketua BPD mengenai pengelolaan badan permusyawaratan desa menerangkan bahwa:

Pengelolaan Badan Permusyawaratan
Desa mengurus anggota-anggota
masyarakat yang terkait dengan badan
permusyawaratan desa. Harapan
mudahan makin baik lagi.

Badan Permusyawaratan Desa (BPD) adalah kegiatan pencatatan data dan informasi mengenai anggota badan permusyawaratan desa. Buku administrasi Badan Permusyawaratan Desa terdiri dari:

1. Buku Data Anggota BPD.

2. Buku Data Keputusan BPD.

3. Buku Data Kegiatan BPD.

4. Buku Data Agenda BPD.

5. Buku Ekspedisi BPD.

Buku administrasi Badan Permusyawaratan Desa dari penelitian di lapangan ditemukan hasilnya sebagai berikut :

\section{Buku Data Anggota BPD}

Pada Kantor Desa Sungai Sipai, Buku Data Anggota BPD bersifat lengkap.

Cara pengisian:

Kolom 1 Diisi dengan nomor secara berurut sesuai dengan jabatan pada Badan Permusyawaratan Desa.

Kolom 2 Diisi dengan nama lengkap anggota.

Kolom 3 Diisi dengan nomor induk anggota.

Kolom 4 Diisi dengan jenis kelamin anggota.

Kolom 5 Diisi dengan tempat/kota kelahiran dan tanggal, bulan serta tahun kelahiran anggota.

Kolom 6 Diisi dengan agama yang dianut.

Kolom 7 Diisi dengan jabatan.

Kolom 8 Diisi dengan pendidikan formal terakhir.

Kolom 9 Diisi dengan nomor serta tanggal, bulan dan tahun keputusan pengangkatan.

Kolom 10 Diisi dengan nomor serta tanggal, bulan dan tahun keputusan pemberhentian.

Kolom 11 Diisi dengan catatan-catatan lain yang dianggap perlu.

\section{Buku Data Keputusan BPD}

Pada Kantor Desa Sungai Sipai, Buku Data Keputusan BPD bersifat lengkap.

Cara pengisian: 
Kolom 1 Diisi dengan secara berurutan sesuai dengan nomor peraturan/ keputusan BPD yang ditetapkan.

Kolom 2 Diisi dengan nomor, tanggal, bulan, dan tahun peraturan/keputusan BPD.

Kolom 3 Diisi dengan judul/penanaman peraturan/keputusan BPD.

Kolom 4 Diisi dengan secara singkat dengan materi pokok yang telah ditetapkan dengan peraturan/ keputusan BPD.

Kolom 5 Diisi dengan catatan-catatan yang dianggap perlu.

\section{Buku Data Kegiatan BPD}

Pada Kantor Desa Sungai Sipai, Buku Data Kegiatan BPD bersifat lengkap.

Cara pengisian:

Kolom 1 Diisi dengan nomor secara berurutan sesuai dengan kegiatan BPD yang dilaksanakan.

Kolom 2 Diisi dengan hari dan tanggal, bulan, taun kegiatan.

Kolom 3 Diisi dengan jenis kegiatan.

Kolom 4 Diisi dengan personil/anggota BPD yang melaksanakan kegiatan dimaksud

Kolom 5 Diisi dengan agenda yang dilaksanakan dan apa yang dihasilkan dari pelaksanaan kegiatan.

Kolom 6 Diisi dengan catatan-catatan yang dianggap perlu.

\section{Buku Data Agenda BPD}

Pada Kantor Desa Sungai Sipai, Buku Data Agenda BPD bersifat lengkap.

Cara pengisian:

Kolom 1 Diisi dengan nomor secara berurut sesuai dengan urutan surat masuk yang diterima.

Kolom 2 Diisi dengan tanggal surat masuk.

Kolom 3 Diisi dengan nomor surat masuk.
Kolom 4 Diisi dengan tanggal, bulan, dan tahun surat masuk.

Kolom 5 Diisi dengan nama instansi yang mengirimkan surat.

Kolom 6 Diisi dengan hal dan isi singkat surat masuk.

Kolom 7 Diisi dengan catatan-catatan yang dianggap perlu.

\section{Buku Ekspedisi BPD}

Pada Kantor Desa Sungai Sipai, Buku Ekspedisi BPD bersifat lengkap.

Cara pengisian:

Kolom 1 Diisi dengan nomor secara berurut sesuai dengan surat yang dikirim.

Kolom 2 Diisi dengan tanggal pengiriman surat.

Kolom 3 Diisi dengan tanggal dan nomor surat yang dikirim.

Kolom 4 Diisi dengan hal dan isi singkat surat yang dikirim.

Kolom 5 Diisi dengan instansi yang dituju.

Kolom 6 Diisi dengan catatan-catatan yang dianggap perlu.

Dari 5 model Buku Administrasi Badan Permusyawaratan Desa lengkap. Pengelolaan buku-buku tersebut dikelola dengan efektif berdasarkan peraturan yang ditetapkan.

\section{F. Pengelolaan Buku Administrasi Lainnya}

Berdasarkan keterangan dari Aparatur Pemerintah Desa di Kantor Pambakal Sungai Sipai Martapura Kabupaten Banjar, pengelolaan buku administrasi lainnya bersifat rahasia karena hanya Kepala Desa yang memegang dan mengelola buku administrasi lainnya.

\section{KESIMPULAN}

Berdasarkan hasil penelitian dan pembahasan tentang Pengelolaan Buku Administrasi Desa Di Kantor Pambakal Sungai Sipai Desa Sungai Sipai Kecamatan Martapura Kabupaten Banjar berdasarkan Peraturan Menteri Dalam Negeri Republik Indonesia Nomor 47 tahun 2016 tentang Administrasi 
Pemerintahan Desa dalam pasal 4 mengenai penyelenggaraan administrasi pemerintahan desa, maka peneliti memberikan kesimpulan bahwa:

1. Dalam pengelolaan administrasi desa terdapat beberapa model buku administrasi desa yaitu, buku administrasi umum, buku administrasi penduduk, buku administrasi keuangan, buku administrasi pembangunan, buku administrasi badan permusyawaratan desa, dan buku administrasi lainnya. Di Desa Sungai Sipai buku administrasi desa tersebut sudah lengkap, tetapi secara rinci masih ada yang kurang.

2. Buku administrasi umum terdiri dari buku data peraturan desa, buku data keputusan kepala desa, buku data inventaris desa, buku data aparat pemerintah desa, buku data tanah milik desa/tanah kas desa, buku data tanah desa, buku agenda, dan buku ekspedisi. Buku Administrasi Umum dikelola oleh Bidang Kepala Urusan Pemerintahan Kantor Pambakal Sungai Sipai Martapura. Dari hasil penelitian buku administrasi umum masih ada yang belum lengkap yaitu buku data inventaris desa dan buku data tanah milik desa/tanah kas desa, karena pengurusan dan pengawasan yang kurang efektif terhadap barang-barang milik Negara maupun milik swasta serta tidak memiliki tanah yang berasal dari kekayaan asli desa, dibeli atau diperoleh atas beban Anggaran Pendapatan dan Belanja Desa (APBDes) atau perolehan hak lainnya yang sah.

3. Buku administrasi penduduk terdiri dari buku data induk penduduk, buku data mutasi penduduk, buku data rekapitulasi jumlah penduduk akhir bulan, dan buku data penduduk sementara. buku administrasi penduduk juga dikelola oleh Bidang Kepala Urusan Pemerintahan Kantor Pambakal Sungai Sipai Martapura. Dari hasil penelitian buku-buku sudah lengkap.

4. Buku Administrasi Keuangan terdiri dari Buku Anggaran Penerimaan, Buku Anggaran Pengeluaran Rutin, Buku Anggaran Pengeluaran Pembangunan,
Buku Kas Umum, Buku Kas Pembantu Penerimaan, Buku Kas Pembantu Pengeluaran Rutin, dan Buku Kas Pembantu Pengeluaran Pembangunan. Buku Administrasi Keuangan dikelola oleh Bendahara Kantor Pambakal Sungai Sipai Martapura. Buku-buku tersebut masih ada yang tidak lengkap yaitu buku anggaran pengeluaran pembangunan, karena bendahara desa tidak mengelola pengeluaran keuangan pembangunan.

5. Buku Administrasi Pembangunan terdiri dari Buku Rencana Pembangunan, Buku Kegiatan Pembangunan, Buku Inventaris Proyek, dan Buku Kader Pembangunan. Buku Administrasi Pembangunan dikelola oleh bidang Kepala Urusan Pembangunan Kantor Pambakal Sungai Sipai Martapura. Dari hasil penelitian di Kantor Pambakal Sungai Sipai buku administrasi pembangunan sudah lengkap.

6. Buku Administrasi Badan Permusyawaratan Desa terdiri dari Buku Data Anggota BPD, Buku Data Keputusan BPD, Buku Data Kegiatan BPD, Buku Data Agenda BPD, dan Buku Ekspedisi BPD. Buku Administrasi Badan Permusyawaratan Desa dikelola oleh Ketua Badan Permusyawaratan Desa di Desa Sungai Sipai Kecamatan Martapura Kabupaten Banjar. Dari hasil penelitian di Kantor Pambakal Sungai Sipai buku administrasi badan permusyawaratan desa sudah lengkap.

7. Buku Administrasi Lainnya adalah kegiatan pencatatan data dan informasi mengenai penyelenggaraan pemerintahan desa, pelaksanaan pembangunan, pemberdayaan masyarakat, dan hubungan masyarakat. Administrasi Lainnya bersifat rahasia karena bersangkutan dengan profil desa. Buku Administrasi Lainnya dikelola sendiri oleh Kepala Desa Sungai Sipai Kecamatan Martapura Kabupaten Banjar.

\section{REFERENSI}

Daft, Richard L. 2006. Manajemen. Jakarta: Erlangga. 
Peraturan Menteri Dalam Negeri Republik Indonesia Nomor 47 Tahun 2016 Tentang Administrasi Pemerintahan Desa

Sondang, P. Siagian. 2001. Kerangka Dasar Ilmu Administrasi. Jakarta: Rineka Cipta Cetakan 2.

Wasistiono, Sadu dan Irwan Tahir, M. 2006. Prospek Pengembangan Desa. Bandung: CV. Fokusmedia.

Widjaja, H. AW. 1993. Pemerintahan Desa Dan Administrasi Desa. Jakarta: PT Raja Grafindo Persada.

Widjaja, H. AW. 2001. Pemerintahan Desa/Marga. Jakarta: PT RajaGrafindo Persada. 